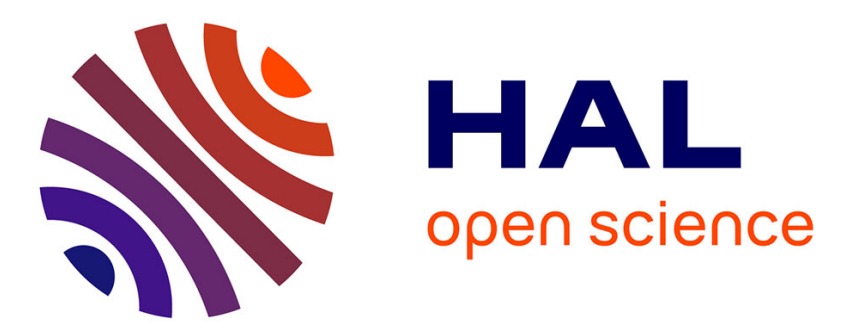

\title{
Common values? Fifty-two cases of value semantics copying on corporate websites
}

\author{
Steffen Roth
}

\section{To cite this version:}

Steffen Roth. Common values? Fifty-two cases of value semantics copying on corporate websites.

Human Systems Management, 2013, 32 (4), pp.249-265. 10.3233/HSM-130801 . hal-01053523

\section{HAL Id: hal-01053523 \\ https://hal.science/hal-01053523}

Submitted on 31 Jul 2014

HAL is a multi-disciplinary open access archive for the deposit and dissemination of scientific research documents, whether they are published or not. The documents may come from teaching and research institutions in France or abroad, or from public or private research centers.
L'archive ouverte pluridisciplinaire HAL, est destinée au dépôt et à la diffusion de documents scientifiques de niveau recherche, publiés ou non, émanant des établissements d'enseignement et de recherche français ou étrangers, des laboratoires publics ou privés. 
Published version available at:

http://steffenroth.files.wordpress.com/2013/12/hsm-common-values.pdf

\title{
COMMON VALUES? FIFTY-TWO CASES OF VALUE SEMANTICS COPYING ON CORPORATE WEBSITES
}

\author{
Dr. Steffen Roth \\ Assistant Professor \\ ESC Rennes School of Business \\ 2 Rue Robert d'Arbrissel \\ FR-35000 Rennes \\ steffen.roth@esc-rennes.fr
}

Abstract: The present article claims that value communication literally goes without saying. Research in organizational value communication as in corporate image documents is therefore assumed to have nothing to do with the analysis of explicit value semantics. This system-theoretical claim is supported by an analysis of corporate value semantics, which is particularly focused on the copying of value semantics from one corporate website to another. As a result, we present a list of 52 companies that have copied value statements from corporate websites of RobecoSAM sector leaders listed in the DJSI. In referring to these examples, we demonstrate that the copying of value semantics makes the best case for exercising caution when it comes to the idea that value semantics promote organizational goals. Finally, we suggest that the value copying affects corporate value communication in a same vein as spam impairs the use of email and argue for an analytical turn from research in communication on values to research in value communication, which opens up new spaces for a management through allusion and, in doing so, could complement the more popular approaches to a management by value metaphors.

Keywords: Organizational values; value semantics; value communication; information ethics; corporate websites; plagiarism; social systems.

\section{Food first, then morality. An introduction}

True to Bertolt Brecht, moral values have long been highlighted as added values [9] and have finally been discovered as a competitive advantage [16]. The following ethical turn in management [3], however, had not yet been consummated when the recent crises proved Brecht right once again. In fact, the economic crises seem to have also uncovered a moral crisis [26], which is in the fact that the increasing popularity of business ethics is countered by a significant decrease in corporate giving [11]. Obviously, companies would rather contribute soft words than hard money, again. Still, however, there is an on-going discourse on how value statements impact an organization's book value, promote human ideals, or can be employed to pursue organizational goals $[10 ; 17 ; 21]$. 
In the present article, we are taking these tensions between the different messages as a message itself. In understanding this message, however, we do not consider it information on the difference between espoused and enacted values [5], between intended and realized strategies or images [8; 15], between talk and practice [6], between instrumental and genuine CSR [11], between self- or societal interest [12], between the is and the ought of value-based management [7], or on the fact that it is hard to find ideals without ideology [21]. In fact, the issue with these most instructive approaches to the moral dimension of management and organization is that they all feature a moral dimension themselves in terms of an obvious bias to one of the two sides of the key distinction they promote, which usually is also assumed to be closer to what is considered the (needed) real values of the organization concerned. Larger parts of the approaches therefore implicitly practice rather than merely study or model business ethics or value-based management. The aim of our contribution, however, is not a claim for value relativism either. Rather, we support the idea that management systems models should reflect their underpinnings and consider conceptual offers from systems thinking [cf. 19], and that this call for reflection should not stop at concepts as fundamental as organizational and management values.

In the following, we will base on a system-theoretical definition of value communication [13], distinguish between communication on values and value communication, and claim that communication on values does not provide any direct information about organizational value communication. This assumption is corroborated by examples of one company copying the value statement of another company. In fact, if a company copies the values of another, then we would assume that these apparently copied values hardly count for the copying company rather than that both companies share exactly the same values. Against the background of this consideration, we will present and discuss a list of 52 companies from all continents that have apparently copied value and mission statements from corporate websites of companies listed in the Dow Jones Sustainability Index (DJSI). Following the theory statement, we will show how we have compiled the list and finally discuss its relevance for future research in corporate websites as reliable and easy accessible sources of information on business values.

\section{Promise you have been true. A theory statement on things that go without saying}

The distinction of social structures and semantics [2;22] is counted among the most relevant distinctions in social systems theory [23] and guides the majority of the few empirical system theoretical research ventures. Like all systems, semantics are differences that make a difference [4]. The difference made by value semantics, as compared to value communication as a social structure, is important. If we need to speak out what should go without saying, the we raise suspicion. This is the case whenever we communicate on values rather than communicating them, just because the "concept of value denotes preferences the validity of which can safely be assumed in social communication without having to face disagreement" [13]. Values are indeed valid only if they can be imputed in communication rather than directly expressed:

"Apparently, the most conspicuous characteristic of values is that they can be communicated inconspicuously. Corresponding to their presumed absolute validity, values are implied as allusions in social communication. (...) While communication itself focuses on issues that can be negotiated and disagreed upon, values remain latent in communication. Values are reproduced and stabilized through indirect communication" [14].

Accordingly, values are existent only as things that literally go without saying. This also means that if values are explicitly addressed, then we can be sure that these values are already contested, that they obviously do not go without saying, and they are no longer values. The recent rise of explicit corporate communication on values therefore is hardly an indicator for a rise of value 
communication. Rather, the opposite is true. Consequently, analyses of "written organizational documents like homepages or glossy brochures" [24] do not lead to a better understanding of organizational value communication. Rather, we could assume that, at least in some cases, there is a systemic discrepancy between the officially listed value semantics and an organization's value communication not only occur because organizations can hardly meet all expectations directed to them, but also because organizations learn to use value semantics as moral shields and explore the new options that emerge behind them [11;24]. The implicit message of such a strategic use of the elasticity of value semantics, however, is that the commitment to the respective values obviously does not go without saying.

In the following, we suggest distinguishing value communication as social structure from communication on values in terms of value semantics. In concrete terms, we will focus on the special case of the copying of value semantics from one organizational self-description to another. This is done in order to stress the importance of the distinction of value communication and communication on values, only the latter of which can actually be copied. In concrete terms, we will present 52 cases of companies that apparently copied and pasted value semantics from DJSI-listed RobecoSAM Sector Leaders 2013 [18] to their own website and discuss possible interpretations of the value communication involved in the fact that one company copies the values of another.

\section{Goodwill hunting. A plagiarism check}

The aim of the present research is to make cases for the importance of the so far seemingly idle distinction between value communication and communication on values. Our main argument for the relevance of this distinction is the idea that a company that merely copies the value statements of another could hardly be thought of as featuring the stated values. In order to underlay this thought experiment with concrete examples, our quest has been for companies that apparently copyied the value statements of others.

Our investigation of companies that apparently copied value statement from other companies started from the assumption that the periphery of the world economy copies values from the centres rather than vice versa. The second assumption we have made was that the copying companies would copy easy-access original material provided by companies that are considered particularly socially responsible and value-driven. We therefore analysed value statements provided on the corporate websites of companies listed in the DJSI, and among these, those of the 58 RobecoSAM Sector Leaders 2013 [18]. In doing so, we focused not on the content of value statements, but rather on the question of whether or not it had been copied.

Browsing the 58 websites, we copied and pasted value statements into a number of online plagiarism checkers such as plagscan.com, grammerly.com, or duplichecker.com. As the majority did not prove to be reliable, we finally preferred to simply use the Google search engine to check for occurrences of corporate value statements on websites other than the respective corporate website. In most cases, a simple inquiry on the statement in question put into inverted commas resulted in a manageable number of matches. In cases of prominent value statements, the quote has been combined with the string "-company name".

\section{Got some values? Screenshots of 52 value Nirvanas}

As a result of our chase for copycat companies, we picked 52 examples of companies that apparently copied other companies value statements to their own website, the names of which are listed in Table 1, as are the names of the respective companies that provided what can be consid- 
ered the original source. ${ }^{1}$

Insert Table 1 about here

The list of the 32 out of 58 RobecoSAM Sector Leaders 2013, whose value statements have not been copied, includes AirFrance-KLM, Amadeus IT, ArcelorMittal, Baxter International, Benesse Holdings, Bombardier, British American Tobacco, Delta Electronics, Electrolux, Fiat Industrial, Gamesa Tecnologia, Gas Natural SDG, GPT, GS Engineering and Construction, Itausa Investimentos Itau, J Sainsbury, Koninklijke Philips Electronics, KT, Lotte Shopping, Molson Coors Brewing, Pirelli, Pesol, Roche, SAP, SK Telecom, Suez Environnement, Sumitomo Forestry, Swiss Re, Tabcop, Telenet, TUI, and UPM-Kymmene. The remaining 26 companies' value statements have apparently been copied at least once by one of the 52 companies listed in Table 1, with the main targets of copycat companies being Akzo Nobel (eight cases of apparently copied value statements), Unilever (seven), Wipro (five), and Siemens (four).

The scope of seemingly copying companies is vast, spanning across all industries and the entire globe. Only in about one third of the cases, the copies have run off within the same or neighbouring industries. In terms of politico-economic distribution, in about half the cases, a firm headquartered in an emerging or developing economy apparently copied the value statements of a company based in a developing company. In one third of the cases, however, it has been a company based in a developed economy that copied from another company based in a developed economy, sometimes even within the same country. The only constellation we did not find is the case of a company from a developed economy copying the values from an emerging or developing economy.

One clear finding is that value copying seems to be a matter of SME rather than larger corporations, which does not mean that there is no such thing as coypcat companies that are listed at the stock exchange. Examples of larger firms that apparently copied value statements from others include Bidco Oil Refineries, Indus Tower, and Scottish Power, the latter of which represents one of the few borderlines case between corporate copying and self-copying of value statements ${ }^{2}$. In fact, in 2006, Scottish Power became a subsidiary of Iberdrola, the company, whose value statements it apparently copied onto its website. In contrast, a prime example of corporate selfcopying is the DJSI-listed mining company Anglo American, which copied value statements from its own website into a letter to the attention of the Australian Federal Senate on March 8, 2013. Rather different is the case of Indus Tower, an Indian joint venture owned by Vodafone Group as well as further partners, some of which maintain only indirect relationships to AlcatelLucent (whose statements have been copied in this case). Bidco Oil Refineries does not display any closer relationship to the chemical company, Akzo Nobel, whose value statements the vegetable oil producer shares on its website. The majority of cases, however, represent SME with 1300 members.

Apart from rare examples at the borderline of self-copying, the present cases feature a broad scope of copying strategies ranging from the unquoted use of only one significant sentences (e.g. Bach SL, Houthoff Buruma) to the copying of larger parts of the content and sometimes even entire documents. For example, the entire business principles of Mezzan Holdings are apparently

1 Evidence for the respective copying activities is presented in Table 2 available at http://steffenroth.files.wordpress.com/2013/06/13-06-13-polly-wants-a-cracker-annex.pdf.

${ }^{2}$ Pairs of companies have been double-checked for possible associations and overlapping ownership structures. 
very close to a full copy of the official "Business Principles" document of former TNT NV, now PostNL (cf. Table 2, annex). In fact, copies of several 100 words are not at all uncommon. Companies such as Axesud Corporation and Rudisa Holding even pursue exactly the same corporate purpose as Unilever. Sometimes we also found CEOs who passed full mission statements of prominent colleagues off as their own (Al Hahiry Group, Pro Factory Resources Ltd). The most obvious case of a copycat company certainly is Zoonar Oil and Gas, which apparently copied AMECs entire CSR statement, thus also claiming to be part of the DJSI-ranking.

As to the formal structure of the copying activities, we finally found that the first and the last quarter of the DJSI-listed sector leaders drew in $38 \%$ or $33 \%$ of the copies, respectively. Accordingly, those companies, which represent $50 \%$ of the sample, have been the targets of almost three quarters of the overall copying activities.

\section{Replicative loss. A discussion on the value of copied values}

Reviewing the copying strategies of the 52 apparently copying companies one of the most striking findings is the sometimes virtually non-existent industry coherence between the copycat and its role model. Common sense would suggest that cases, in which companies - like Sportsware International or Prosertec Ingenieria - apparently copy Adidas or Iberdrola, respectively, are the rule. Our findings, however, rather suggest the opposite. Intra-industry value copying accounts for only one third of the overall copying activities. In the remaining cases, we are left with questions such as why an Australian anti-graffiti service provider copies the value statement of the Anglo-Dutch consumer goods company Unilever. If we combine this finding with the fact that almost three quarters of the presumptive victims are located in the first or the last quarter of the reference list, we can consider this an indicator for the fact that the reasons for the copying of value semantics are rather not due to their content. And even if there were content-related reasons for why a Tokyo-based business consultancy (Adam Innovation) picks its values from the litter (Waste Management Inc.), the question remains as to why companies seem to have a need for copying other company's value statements, and why these copying activities are carried out even by companies operating in a value sensitive environment such as German biofuel expert Sprint Energies, who obviously has the same credo as Danish biotechnology company, Novozymes.

It is against the background of these questions that we are stressing the distinction of organizational value communication and communication on organizational values, the importance of which is even higher if we draw our attention to the example of the mission statement of the USbased detention equipment company Southern Folge. In looking at the content, everything sounds perfect except for the humour involved in the fact that the statement, "we independently determine our own pricing (...) and do not make agreements with competitors to divide markets or clients" (cf. Table 2, annex; own emphasize), is made by a company that has seemingly been unable to independently compose its own mission statement. If we go on pointing to the fact that the statement has apparently been copied from French hospitality service giant, Sodexo, then the link between a hotel and a prison could give the value communication understood in this context a bit of a cynical touch. Noting however that Sodexo itself obviously has a broad concept of hospitality and, accordingly, provides services in many sectors such as schools, universities, hospitals, clinics, military bases and prisons, might change the picture once again. The information on Sodexo's own bias to total institutions might influence our value judgement on the copycat company again. Now we might find that the cynicism is maybe less in Southern Folger's presumptive copying, but rather in Sodexo's business strategy.

The as short as eventful semantic journey we have just made clearly shows that organizational 
value communication is just as little in value semantics itself as the term $1+1=3$ is inherently wrong, ${ }^{3}$ which is a truth that necessarily brings the observer of the values into the communication. This observer is you. Looking at you we find that value communication is neither in what organizations say nor in how big the gap is between this talk and "the real culture of organizations" [25]. Value communication is about the information you understand as an expression of value and about the question of what the "you" is in the previous clause.

Whatever you are, we are sure that you will understand very different things depending on whether you are or are not aware of the fact that the sentence, "These values have real meaning for us", has apparently been copied from AkzoNobel's website to the virtual showcases of companies as different as Pro Factory Resources, Silver Dollar Technology, di-Branch Foundation, Fleet Rohas, and Bidco Oil (cf. Table 2). In fact, we are puzzled why organizations decide to copy such a sentence. It is findings like these that quickly lead us to the borderlands of the paradox, and clearly show that future research in organizational value communication cannot stop at smart analyses of the value semantics used in formal and informal, or public and private settings, respectively.

One form of value communication understood if communication on (the importance of) values is copied is that the copied values mean nothing at all to the copying company. This understanding, however, is just an assumption that calls for further research in corporate value copying. Language issues or further sources of insecurity could also have guided the corresponding decisions. Language issues have also played a role in our research. For example, Spanish gas utilities company Gas Natural SDG SA has been counted among the 32 companies, whose value statements have not been copied, which is true only insofar that we did not find any copies of Englishlanguage statements. Yet, the Spanish-language statements have apparently been copied. However, as the Chinese and Korean language skills of the authors did not allow for a systematic scan of all companies' mother-tongue language areas, we decided to focus exclusively on statements in the English language, which evidently also impacts the value of our findings. Nonetheless, we have been surprised to find so many cases of value copying in-between and even within developed economies, and we have been even more so because our research design started from the assumption that companies from the periphery would copy value statements from the centres of the world economy rather than vice versa and, therefore, systematically supported the detection of corresponding constellations. In fact, our search strategy resonates with the findings insofar that companies based in emerging markets apparently copied values from companies based in both developed and emerging markets, while there is no case of a company from the centre copying a company from the periphery. Against the background of the mentioned bias, and with still more than $30 \%$ of the seemingly copying companies being from developed economies, value copying cannot be discounted as a developing or emerging market phenomenon.

\section{Common values. An outlook on value sharing networks}

In the course of our essentially theory-driven search for cases in which companies apparently copied other companies' value statements, we have found a brush seller with no clean record in terms of value plagiarism, a number of CEOs that passed popular value semantic of renowned business leaders off as their own, and five companies that apparently copied the statement, "These values have real meaning for us", to their website. In total, we have been able to compile a list of 52 companies that apparently copied amounts of text from one significant sentence to several

\footnotetext{
${ }^{3}$ In the context of love scenes from planet earth, the term is commonly considered true.
} 
100 words from a DJSI-listed company's website onto their own. Particularly attractive companies have been those listed at the beginning and at the end of the publically available RobecoSAM DJSI Sector Leaders 2013 list. In addition to the apparently copied company's popularity and certified sustainability, the ease of access to the respective texts can therefore be considered a reason for the copying of the concrete statements. The idea that copycat companies did not focus too much on the content of the apparently copied semantics is also supported by the fact that copying occurred across all geographic areas or industries, respectively, and has in most cases not involved any adaptation at all up to the point where a company like Zoonar Oil and Gas PLC blindly copied AMECs entire CSR statement and, as such, claims to be part of the DJSIranking.

The fact that copying of value statements not only simply occurs, but is done regardless of the content, adds not only more evidence to the claimed relevance of the distinction of value communication and value semantics, but also calls for the consideration of value copying in the context of issues related to the analysis and the design of corporate websites. In any case, the blind copying of a value semantic can be interpreted as a form of value communication that can be understood irrespective of any semantic analysis. In concrete terms, we find that companies that just copy and paste either have a serious CSR problem in terms of a lacking mastery of their own micro-contexts [20] or do not care much about neither the copied values nor values in general. It could also be that the management is not very eloquent but still wants to express their convictions in an agreeable-sounding way. Last not least, there could be cases where staff has just been instructed to write something on CSR or values, which again would be an indicator of the low relevance of value communication as compared to communication on values.

The companies whose value statements have apparently been copied, may now either consider taking action for injunction or choose a more playful attitude to their own values, the latter of which could also mean taking advantage of the fact that the own value semantics are considered worthy copying. Even if the fact that value semantics are copied does not give any information about neither the quality of these semantics nor the value communication the respective company tried to get across, it nonetheless can be considered a form of value communication in itself, as the copier affirms the supremacy of the copied. The companies whose value statements have not been cited can therefore either reconsider their CSR management strategy or take comfort in the assumption that parrots copy sounds, not meaning, which is also in line with the fact that the results show a certain bias to the easy accessible first and the last companies on the list of RobecoSAM Sector Leaders 2013. Further reasons for not being on our list of presumptive copycat victims could have been language barriers on the part of the apparently copying companies or the fact that our research only focused on English language value statements. Another limitation of our research has been our presumption regarding the directions of the copycat-activities, which have their roots in common sense rather than in test and experiment. Further research could therefore not only aim at directional value statement citation network analyses, but also at the use of more efficient plagiarism detection tools, in the context of which an underlying hypothesis could be that the full-copying is predominantly practiced in developing and emerging economies while in developed economies there would occur more paraphrasing of value statements. The idea that in developed economies there might also be a smoother culture of value copying is as obvious as it is momentous in terms of both theory development and empirical research in organizational value communication. In fact, we showed that value communication actually could be understood without any regard of the concrete value semantics. This fact, however, does not at all mean that a systematic analysis of common bases of values semantics cannot produce relevant information. An incidental finding of our research unveiled that "independence, transparency, performance, 
entrepreneurship, excellence and confidentiality" are common values of the Marine King Holdings (UK), Alpenrose Wealth Management (Switzerland), Futureglobal (Dubai), Bio Funds Society (UK), and Amarthya Wealth Management (India). If we do not stop at taking this common statement for a common value fundament, then we can start wondering who has copied whom in this context or even assume that there is maybe a personal or organizational link between these companies. Not only could cyber tax investigators therefore consider common value statements hot scents rather than expressions of deep convictions, but companies might also want to draw their conclusions from this idea and better protect their business-models.

As to mangers, the fact that value communication can be understood even completely irrespective of the concrete value semantics involved might open up a new space for the exploration of management strategies. Against the background of the research presented, mangers might want to consider refocusing their attention from value semantics to value communication and, in doing so, complementing the prominent management by metaphors [1] by management through allusion. 


\section{References}

[1] M. Alvesson, Understanding organizational culture, SAGE Publications Limited, 2012.

[2] N. Andersen, The Semantic Analytical Strategy and Diagnostics of Present, in: Die Methodologien des Systems, R. John, A. Henkel, and J. Rückert-John, eds., VS Verlag für Sozialwissenschaften, 2010, pp. 161-180.

[3] D. Bartlett, Management and Business Ethics: A Critique and Integration of Ethical Decision-making Models, British Journal of Management 14 (2003), 223-235.

[4] G. Bateson, Steps to an ecology of mind: Collected essays in anthropology, psychiatry, evolution, and epistemology, University of Chicago Press, 1972.

[5] J. Beyer and S. Lutze, The ethical nexus: Organizations, values and decision-making, in: The Ethical Nexus., C. Conrad, ed., Ablex NJ, 1993.

[6] S. Clegg, M. Kornberger, and C. Rhodes, Business Ethics as Practice, British Journal of Management 18 (2007), 107-122.

[7] G. de Graaf, Discourse Theory and Business Ethics. The Case of Bankers' Conceptualizations of Customers, Journal of Business Ethics 31 (2001), 299-319.

[8] K. de Roeck, F. Maon, and C. Lejeune, Taking Up the Challenge of Corporate Branding: An Integrative Framework, European Management Review (2013), n/a-n/a.

[9] P.F. Drucker, Ethical chic, Forbes 128 (1981), 160-173.

[10] Y.-H. Hsieh and J.-Y. Chan, Corporate social responsibility: A concern among employees, Human Systems Management 31 (2012), 219-230.

[11] A. Kemper and R.L. Martin, After the fall: The global financial crisis as a test of corporate social responsibility theories, European Management Review 7 (2010), 229-239.

[12] N. Lin-Hi and I. Blumberg, The Link between Self-and Societal Interests in Theory and Practice, European Management Review 9 (2012), 19-30.

[13] N. Luhmann, Are There Still Indispensable Norms in Our Society?, Soziale Systeme 14 (2008), 18-37.

[14] N. Luhmann and S. Fuchs, Tautology and paradox in the self-descriptions of modern society, Sociological Theory 6 (1988), 21-37.

[15] H. Mintzberg, Patterns in strategy formation, Management Science 24 (1978), 934-948.

[16] J. Pimentel, J. Kuntz, and D.S. Elenkov, Ethical decision-making: an integrative model for business practice, European Business Review 22 (2010), 359-376.

[17] P. Pruzan and O. Thyssen, Conflict and consensus: Ethics as a shared value horizon for strategic planning, Human Systems Management 9 (1990), 135-151.

[18] RobecoSAM, The Sustainability Yearbook 2013, in, 2013.

[19] P. Sice, I. French, and E. Mosekilde, An integrated frame-of-reference for modelling management systems, Human Systems Management 25 (2006), 247-254.

[20] A.E. Singer, Global Strategy and Ethics: Managing Human Systems and Advancing Humane Ideals, Business Ethics Quarterly 17 (2007), 341-363.

[21] A.E. Singer, Ideals without ideology, Human Systems Management 27 (2008), 261-271.

[22] U. Stäheli, Exorcising the 'popular' seriously: Luhmann's concept of semantics 1, International Review of Sociology 7 (1997), 127-145.

[23] R. Stichweh, Semantik und Sozialstruktur. Zur Logik einer systemtheoretischen Unterscheidung, in: Neue Perspektiven der Wissenssoziologie, D. Tänzler, H. Knoblauch, and H.-G. Soeffner, eds., UVK, Konstanz, 2006, pp. 157-171. 
[24] V. von Groddeck, Rethinking the Role of Value Communication in Business Corporations from a Sociological Perspective - Why Organisations Need Value-Based Semantics to Cope with Societal and Organisational Fuzziness, Journal of Business Ethics 100 (2011), 69-84.

[25] H. Willmott, Renewing strength: Corporate culture revisited, M@n@gement 6 (2003), 7387.

[26] M. Zollo and E. Freeman, Re-thinking the firm in a post-crisis world, European Management Review 7 (2010), 191-194. 


\section{Biographical note}

Steffen Roth is Assistant Professor of Management and Organization at the ESC Rennes School of Business, France. He was awarded a PhD in management from the Chemnitz University of Technology, and recently defended his second $\mathrm{PhD}$ thesis in organizational sociology at the University of Geneva. He held visiting professorships at the University of Cagliari, the Copenhagen Business School, and the Yerevan State University. His research fields include organizational theory, social systems theory, value communication, social differentiation, and ideation and crowdsourcing.

If any possible, I would prefer to do without the photo. 


\section{Tables}

Table 1: List of companies that apparently copied value statements from RobecoSAM sector leaders 2013 (source: own table).

\begin{tabular}{|c|c|c|c|c|c|}
\hline Copy Company & C-Sector & $H Q$ & Original Company & O-Sector & $\mathrm{HQ}$ \\
\hline Adam Innovations & Consultancy & $J P$ & WasteManagement & Waste Disposal & US \\
\hline Adventure Media & Advertisement & $I N$ & Unilever NV & Food Beverage & NL \\
\hline AKR Global Ltd & Diversified & $C A$ & Enbridge Inc & Infrastructure & $\mathrm{CA}$ \\
\hline Al Hajiry Group & Diversified & $O M$ & ANZ Banking & Banking & $\mathrm{AU}$ \\
\hline Alpha Mgmt & Consultancy & $I N$ & Wipro Ltd & IT Services & IN \\
\hline ARUN (Xiamen) & Manufacturing & $C N$ & Henkel AG & Manufacturing & $\mathrm{DE}$ \\
\hline Axesud Corp & Diversified & $A R$ & Unilever NV & Food Beverage & NL \\
\hline BACH S.L. & Manufacturing & $E S$ & Iberdrola SA & Energy & ES \\
\hline Bidco Oil & Energy & $K E$ & Akzo Nobel NV & Chemicals & NL \\
\hline Caerus Int & Commerce & US & Sonoco Products Co & Logistics & US \\
\hline Codexmind & Web Design & $I N$ & Herman Miller Inc & Furnishing & US \\
\hline di-branch FDN & Consultancy & $N G$ & Akzo Nobel NV & Chemicals & $\mathrm{NL}$ \\
\hline Fargon & Pharmaceuticals & $N L$ & Akzo Nobel NV & Chemicals & NL \\
\hline Fleet Rofhas & Energy & $B N$ & Akzo Nobel NV & Chemicals & $\mathrm{NL}$ \\
\hline Frank Bürsten & Brushes & $D E$ & Siemens AG & Diversified & $\mathrm{DE}$ \\
\hline Global HR & Consultancy & $A E$ & AMEC PLC & Consultancy & GB \\
\hline Hawk Scaffoldings & Construction & $I N$ & Alcoa Inc & Mining & US \\
\hline Henan CFY Ltd & Commerce & $C N$ & Anglo American PLC & Mining & GB \\
\hline Henke Consulting & Consultancy & $D E$ & Siemens AG & Diversified & $\mathrm{DE}$ \\
\hline Houthoff Buruma & Law firm & $N L$ & Siemens AG & Diversified & $\mathrm{DE}$ \\
\hline Huatai Biopharm & Pharmaceuticals & $C N$ & AU Optronics Corp & Electronics & TW \\
\hline ICT Xchange & Software & $H K$ & Akzo Nobel NV & Chemicals & NL \\
\hline Indus Towers & Communication & $I N$ & Alcatel-Lucent SA & Communication & FR \\
\hline Innoexcel Tech & Web Design & $I N$ & Wipro Ltd & IT Services & IN \\
\hline Joshua Energy & Consultancy & $Z A$ & Anglo American PLC & Mining & GB \\
\hline K-Laser Tech & Electronics & $T W$ & Taiwan Semiconductor & Manufacturing & TW \\
\hline Krishna Foils & Manufacturing & $I N$ & Unilever NV & Food Producers & NL \\
\hline Loyok & Textile Footwear & $K R$ & Amorepacific Corp & Chemicals & $\mathrm{KR}$ \\
\hline Mailsoft Solutions & IT Services & $I N$ & Wipro Ltd & IT Services & IN \\
\hline Marchad Group & Diversified & $M Y$ & Wipro Ltd & IT Services & IN \\
\hline Mezzan Holding & Diversified & $K W$ & PostNL NV & Logistics & NL \\
\hline Mostham PTY Ltd & Electronics & $A U$ & Siemens AG & Diversified & $\mathrm{DE}$ \\
\hline Motibhai Group & Diversified & FJ & ANZ Banking & Banks & $\mathrm{AU}$ \\
\hline Oyster Tech & Manufacturing & $P K$ & Unilever NV & Food Beverage & NL \\
\hline ProFactory Res & Commerce & $H K$ & Akzo Nobel NV & Chemicals & $\mathrm{NL}$ \\
\hline Prosertec Ing & Energy & $B O$ & Iberdrola SA & Electricity & ES \\
\hline Rudisa Holidng & Diversified & $S R$ & Unilever NV & Food Beverage & NL \\
\hline Sanchar Telecom & Communication & $I N$ & Alcatel-Lucent SA & Communication & FR \\
\hline SCC Pvt Ltd & IT Service & $I N$ & Wipro Ltd & IT Service & IN \\
\hline Sciformix & Pharmaceuticals & $U S$ & UnitedHealth Inc & Healthcare & US \\
\hline ScottishPower & Energy & $G B$ & Iberdrola SA & Energy & ES \\
\hline Silver Dollar Tech & Software & $I N$ & Akzo Nobel NV & Chemicals & NL \\
\hline Sollan Ltd & Electronics & $C N$ & Lite-On Inc & Electronics & TW \\
\hline Southern Folder & Security & $U S$ & Sodexo & Hospitality & FR \\
\hline Spark Company & Electronics & $B D$ & Siam Cement PCL & Construction & $\mathrm{TH}$ \\
\hline Sportsware Int & Textile Footwear & $G B$ & Adidas AG & Textile Footwear & $\mathrm{DE}$ \\
\hline Sprint Energies & Energy & $D E$ & Novozymes AS & Biotechnology & $\mathrm{DK}$ \\
\hline Sunflex Technology & Electronics & $T W$ & Taiwan Semiconductor & Manufacturing & TW \\
\hline
\end{tabular}




\begin{tabular}{|l|l|l|l|l|l|}
\hline Syrox & Manufacturing & $I I L$ & BMW AG & Automobiles & DE \\
\hline The Graffiti Specialists & Service & $A U$ & Unilever NV & Food Beverage & NL \\
\hline Wrapid Manufacturing & Manufacturing & $G B$ & Unilever NV & Food Beverage & NL \\
\hline Zoonar Oil and Gas & Energy & $G B$ & AMEC PLC & Consultancy & GB \\
\hline
\end{tabular}




\section{Annex}

Table 2: List of copied and original value statement per apparently copying company (source: own table; all websites retrieved May 2013).

\begin{tabular}{|c|c|c|}
\hline Copy Company & Copied statement & Original statement \\
\hline Adam Innovations & $\begin{array}{l}\text { In doing so, we are contributing to a more } \\
\text { sustainable world by: advancing technolo- } \\
\text { gies to reduce waste, increasing recycling } \\
\text { and reuse, creating even safer treatment } \\
\text { and disposal options (plus over } 100 \text { identi- } \\
\text { cal words). }\end{array}$ & $\begin{array}{l}\text { In doing so, we are contributing to a more } \\
\text { sustainable world by: advancing technolo- } \\
\text { gies to reduce waste, increasing recycling } \\
\text { and reuse, creating even safer treatment } \\
\text { and disposal options. }\end{array}$ \\
\hline Adventure Media & $\begin{array}{l}\text { Always working with integrity. Conduct- } \\
\text { ing our operations with integrity and with } \\
\text { respect for the many people, organizations } \\
\text { and environments our business touches has } \\
\text { always been at the heart of our corporate } \\
\text { responsibility (plus over } 100 \text { identical } \\
\text { words). }\end{array}$ & $\begin{array}{l}\text { Always working with integrity. Conduct- } \\
\text { ing our operations with integrity and with } \\
\text { respect for the many people, organizations } \\
\text { and environments our business touches } \\
\text { has always been at the heart of our corpo- } \\
\text { rate responsibility. }\end{array}$ \\
\hline AKR Global Ltd & $\begin{array}{l}\text { We believe that success is rooted in treat- } \\
\text { ing people well. We continue to look for } \\
\text { new ways to enhance lives, and invest in } \\
\text { initiatives that help us do so. AKR Global } \\
\text { invests in a range of initiatives, from pro- } \\
\text { grams geared toward ensuring that our } \\
\text { operations are as safe as possible to pro- } \\
\text { grams designed to engage, inspire, attract } \\
\text { and retain partnerships (plus over } 100 \\
\text { almost identical words). }\end{array}$ & $\begin{array}{l}\text { Enbridge believes that success is rooted in } \\
\text { treating people well. We continue to look } \\
\text { for new ways to enhance the lives of our } \\
\text { employees and stakeholders, and invest in } \\
\text { initiatives that help us do so. These initia- } \\
\text { tives range from programs geared toward } \\
\text { ensuring that Enbridge's operations are as } \\
\text { safe as possible to programs designed to } \\
\text { engage, inspire, attract and retain employ- } \\
\text { ees. }\end{array}$ \\
\hline Al Hajiry Group & $\begin{array}{l}\text { The Al Hajiry Group has an established } \\
\text { market presence, the resources and key } \\
\text { success factors necessary to accelerate its } \\
\text { growth. We are focused on growing our } \\
\text { business responsibly, and approach our } \\
\text { role in society with a heightened sense of } \\
\text { duty and care towards our customers and } \\
\text { the communities we serve. }{ }^{10} \text { (Labelled as } \\
\text { the CEO's own mission statement) }\end{array}$ & $\begin{array}{l}\text { We are focussed on growing our business } \\
\text { responsibly, managing risks rather than } \\
\text { taking them and approach our role in } \\
\text { society with a heightened sense of duty } \\
\text { and care towards our customers and the } \\
\text { communities we serve. }{ }^{11} \text { - Mike Smith, } \\
\text { ANZ CEO }\end{array}$ \\
\hline Alpha Management & $\begin{array}{l}\text { It stems from the belief that corporations } \\
\text { are socio-economic citizens and that their } \\
\text { objectives have to be congruent with socie- } \\
\text { ty's goals. Today, they wield significant } \\
\text { capacity to influence social issues, i.e. } \\
\text { "power to do good". This is a responsibil- } \\
\text { ity and must manifest in thoughtful and }\end{array}$ & $\begin{array}{l}\text { It stems from the belief that corporations } \\
\text { are socio-economic citizens and that their } \\
\text { objectives have to be congruent with soci- } \\
\text { ety's goals. Today, they wield significant } \\
\text { capacity to influence social issues, i.e. } \\
\text { "power to do good". This is a responsibil- } \\
\text { ity and must manifest in thoughtful and }\end{array}$ \\
\hline
\end{tabular}

\footnotetext{
${ }^{4}$ http://www.adam-i.jp/view page.php?main=2\&subTopic=25\&subSubTopic=34

5 http://www.wm.com/sustainability/index.jsp

6 http://www.adventuremedia.in/Purpose $\% 20 \% 20$ Principal.aspx

7 http://www.unilever.com/aboutus/purposeandprinciples/

8 http://canadacreative.zxq.net/csr-healthandsafety.htm

9 http://www.enbridge.com/AboutEnbridge/CorporateSocialResponsibility/Social.aspx

${ }^{10} \mathrm{http}: / / \mathrm{www}$.alhajiry.com/executive-management/

11 http://www.anz.com.au/about-us/corporate-responsibility/
} 


\begin{tabular}{|c|c|c|}
\hline & $\begin{array}{l}\text { deliberate set of initiatives, not in charity. } \\
\text { These must reflect the same level of rigor } \\
\& \text { strategic thinking as in business initia- } \\
\text { tives. Innoexcel believes it must try to, and } \\
\text { can make (some) lasting impact, towards } \\
\text { creating a just, equitable, humane \& sus- } \\
\text { tainable society (plus } 34 \text { almost identical } \\
\text { words). }\end{array}$ & $\begin{array}{l}\text { deliberate set of initiatives, not in charity. } \\
\text { These must reflect the same level of rigor } \\
\& \text { strategic thinking as in business initia- } \\
\text { tives. Wipro believes it must try to, and } \\
\text { can make (some) lasting impact, towards } \\
\text { creating a just, equitable, humane \& sus- } \\
\text { tainable society. }\end{array}$ \\
\hline ARUN (Xiamen) & $\begin{array}{l}\text { We put our customers at the center of what } \\
\text { we do We anticipate, respond to and meet } \\
\text { our customers' and consumers' expecta- } \\
\text { tions by providing the best value, quality, } \\
\text { and most innovative services and prod- } \\
\text { ucts. }{ }^{14}\end{array}$ & $\begin{array}{l}\text { We put our customers at the center of } \\
\text { what we do. We anticipate, respond to and } \\
\text { meet our customers' and consumers' ex- } \\
\text { pectations by providing the best value, } \\
\text { quality, and most innovative brands and } \\
\text { technologies. }{ }^{15}\end{array}$ \\
\hline Axesud Corp & $\begin{array}{l}\text { Always working with integrity. } \\
\text { Conducting our operations with integrity } \\
\text { and with respect for the many people, } \\
\text { organizations and environments our busi- } \\
\text { ness touches has always been at the heart } \\
\text { of our corporate responsibility (plus over } \\
100 \text { identical words). }{ }^{16}\end{array}$ & $\begin{array}{l}\text { Always working with integrity. Conduct- } \\
\text { ing our operations with integrity and with } \\
\text { respect for the many people, organizations } \\
\text { and environments our business touches } \\
\text { has always been at the heart of our corpo- } \\
\text { rate responsibility. }\end{array}$ \\
\hline BACH S.L. & $\begin{array}{l}\text { BACH is committed to the best corporate } \\
\text { governance practices, to principles of } \\
\text { business ethics, and to transparency in all } \\
\text { of the company's fields of endeavor. }{ }^{18}\end{array}$ & $\begin{array}{l}\text { IBERDROLA is committed to the best } \\
\text { corporate governance practices, to princi- } \\
\text { ples of business ethics, and to transparen- } \\
\text { cy in all of the Company's fields of en- } \\
\text { deavor. }{ }^{19}\end{array}$ \\
\hline Bidco Oil & $\begin{array}{l}\text { Our values give us standards to measure } \\
\text { ourselves by, particularly in our dealings } \\
\text { with customers, Suppliers, our own people } \\
\text { and the wider community. These values } \\
\text { have real meaning for us and the way we } \\
\text { behave. }\end{array}$ & $\begin{array}{l}\text { Our values give us standards to measure } \\
\text { ourselves by, particularly in our dealings } \\
\text { with customers, suppliers, our own people } \\
\text { and the wider world. The values have real } \\
\text { meaning for us and the way we behave. }{ }^{21}\end{array}$ \\
\hline Caerus International & $\begin{array}{l}\text { Caerus International's sustainability goals } \\
\text { are being realized by focusing on continu- } \\
\text { ous improvement in operating perfor- } \\
\text { mance, maintaining an ongoing commit- } \\
\text { ment to social responsibility and shrinking } \\
\text { the environment footprint of the compa- } \\
\text { ny. }\end{array}$ & $\begin{array}{l}\text { Sonoco's sustainability goals are being } \\
\text { realized by focusing on continuous im- } \\
\text { provement in operating performance, } \\
\text { maintaining an ongoing commitment to } \\
\text { social responsibility and shrinking the } \\
\text { environmental footprint of the Company. }\end{array}$ \\
\hline Codexmind & $\begin{array}{l}\text { We respect all expressions of human talent } \\
\text { and potential. We value the unique per- } \\
\text { spectives, qualities, and contributions of }\end{array}$ & $\begin{array}{l}\text { We respect all expressions of human tal- } \\
\text { ent and potential. We value the unique } \\
\text { perspectives, qualities, and contributions }\end{array}$ \\
\hline
\end{tabular}

\footnotetext{
${ }^{12} \mathrm{http}: / /$ www.alphamanagementconsultancy.com/AboutUs.php

${ }_{13}^{13}$ http://www.wipro.com/about-wipro/sustainability/

${ }^{14} \mathrm{http}: / /$ www.china-arun.com/Abouts.asp? SortID $=34$

$15 \mathrm{http} / / / \mathrm{www} \cdot h e n k e l . c o m / a b o u t-h e n k e l / v i s i o n-a n d-v a l u e s-11781 . \mathrm{htm}$

${ }^{16} \mathrm{http}: / /$ www.axesudcorp.com/\#!solutions

${ }^{17} \mathrm{http}: / /$ www.unilever.com/aboutus/purposeandprinciples/

$18 \mathrm{http}: / /$ www.bach-sl.com/en/about-us/mission-and-values.htm

$19 \mathrm{http://www.iberdrola.es/webibd/corporativa/iberdrola?IDPAG}=$ ENWEBCONEMPGVISIONYVAL

${ }^{20} \mathrm{http}: / /$ www.bidco-oil.com/ourteam/employeedetails.aspx?EID=13

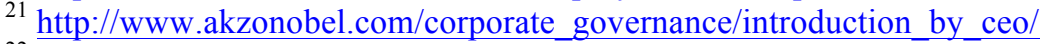

${ }^{22} \mathrm{http} / / / \mathrm{www}$. caerusinternational.com/values-responsibility/

$23 \mathrm{http://www.sonoco.com/sustainability.aspx}$
} 


\begin{tabular}{|c|c|c|}
\hline & $\begin{array}{l}\text { every person in our community. WE } \\
\text { WORK FOR A BETTER WORLD. The } \\
\text { opportunity to contribute to a better world } \\
\text { makes our work meaningful and reward- } \\
\text { ing. TRANSPARENCY IS ONE OF OUR } \\
\text { GOALS. We let each other see how deci- } \\
\text { sions get made. We take responsibility for } \\
\text { the decisions we make. }^{24}\end{array}$ & $\begin{array}{l}\text { of every person in our community. A } \\
\text { Better World. The opportunity to contrib- } \\
\text { ute to a better world makes our work } \\
\text { meaningful and rewarding. Transparency. } \\
\text { We let each other see how decisions get } \\
\text { made. We take responsibility for the deci- } \\
\text { sions we make. }\end{array}$ \\
\hline di-branch Foundation & $\begin{array}{l}\text { Our values. Our values give us standards } \\
\text { to measure ourselves by, particularly in } \\
\text { our dealings with customers, suppliers, our } \\
\text { own people and the wider world. The val- } \\
\text { ues have real meaning for us and the way } \\
\text { we behave. (...) Above all, we're commit- } \\
\text { ted to creating long-term value for our } \\
\text { customers, shareholders, employees and } \\
\text { society. We need to make sustainable } \\
\text { profits if our business is to thrive.We have } \\
\text { trained employees worldwide on these } \\
\text { principles, and we continue to think and } \\
\text { act according to them on a daily basis. In } \\
\text { order to help us maintain this focus, we } \\
\text { have developed different services blended } \\
\text { to meet every needs. }{ }^{26}\end{array}$ & $\begin{array}{l}\text { Our values. Our values give us standards } \\
\text { to measure ourselves by, particularly in } \\
\text { our dealings with customers, suppliers, } \\
\text { our own people and the wider world. The } \\
\text { values have real meaning for us and the } \\
\text { way we behave. (...) Above all, we're } \\
\text { committed to creating long-term value for } \\
\text { our customers, shareholders, employees } \\
\text { and society. We need to make sustainable } \\
\text { profits if our business is to thrive. We have } \\
\text { trained employees worldwide on these } \\
\text { principles, and we continue to think and } \\
\text { act according to them on a daily basis. In } \\
\text { order to help us maintain this focus, we } \\
\text { have developed the AkzoNobel Code of } \\
\text { Conduct. }\end{array}$ \\
\hline Fargon & $\begin{array}{l}\text { Our values give us standards to measure } \\
\text { ourselves by, particularly in our dealings } \\
\text { with customers, suppliers, our own people } \\
\text { and the wider world. The values have real } \\
\text { meaning for us and the way we behave. }{ }^{28}\end{array}$ & $\begin{array}{l}\text { Our values give us standards to measure } \\
\text { ourselves by, particularly in our dealings } \\
\text { with customers, suppliers, our own people } \\
\text { and the wider world. The values have real } \\
\text { meaning for us and the way we behave. }{ }^{29}\end{array}$ \\
\hline Fleet Rofhas & $\begin{array}{l}\text { Our Values. Our values give us standards } \\
\text { to measure ourselves by particularly in our } \\
\text { dealings with customers, associates, affili- } \\
\text { ates and our own people within the Group. } \\
\text { The values have real meaning for us and } \\
\text { the way we behave. (...) Above all, we're } \\
\text { committed to creating long-term value for } \\
\text { our customers, shareholders, employees } \\
\text { and society (plus over } 100 \text { almost identical } \\
\text { words). }{ }^{30}\end{array}$ & $\begin{array}{l}\text { Our values. Our values give us standards } \\
\text { to measure ourselves by, particularly in } \\
\text { our dealings with customers, suppliers, } \\
\text { our own people and the wider world. The } \\
\text { values have real meaning for us and the } \\
\text { way we behave. (...) Above all, we're } \\
\text { committed to creating long-term value for } \\
\text { our customers, shareholders, employees } \\
\text { and society. }{ }^{31}\end{array}$ \\
\hline Frank Bürsten & $\begin{array}{l}\text { For us, sustainability means acting in the } \\
\text { best interest of coming generations with } \\
\text { respect to the environment and society. }\end{array}$ & $\begin{array}{l}\text { For us, sustainability means acting in the } \\
\text { best interest of coming generations - with } \\
\text { respect to the economy, the environment } \\
\text { and society. }\end{array}$ \\
\hline Global Human Re- & Global Human Resources is a company & AMEC is a company with a clear vision, a \\
\hline
\end{tabular}

\footnotetext{
${ }^{24} \mathrm{http}: / /$ www.codexmind.com/aboutus.html

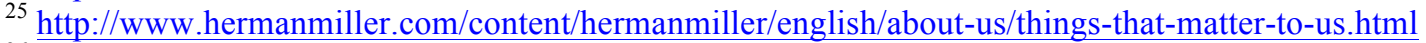

${ }^{26} \mathrm{http://di-branch.jimdo.com/our-values/}$

${ }^{27} \mathrm{http} / / / \mathrm{www} . a k z o n o b e l . c o m / c o r p o r a t e ~ g o v e r n a n c e /$ introduction by ceo/

$28 \mathrm{http://www.fagron.com/en/values}$

${ }^{29} \mathrm{http}: / / \mathrm{www} \cdot$ akzonobel.com/corporate governance/introduction by ceo/

${ }^{30} \mathrm{http}: / /$ fleet-group.org/the-way-we-do-business.html

${ }^{31} \mathrm{http} / / / \mathrm{www} \cdot a k z o n o b e l . c o m / c o r p o r a t e ~ g o v e r n a n c e /$ introduction by ceo/

${ }^{32} \mathrm{http}: / /$ www.frank-brushes.de/cms/about-us/ecological-production/

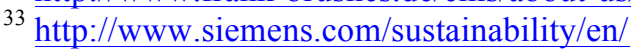




\begin{tabular}{|c|c|c|}
\hline sources & $\begin{array}{l}\text { with a clear vision, a common sense of } \\
\text { direction and a culture of performance and } \\
\text { delivery. Our aim is to create a successful, } \\
\text { sustainable company for the long term. To } \\
\text { achieve this we need to balance economic, } \\
\text { social and environmental issues in our } \\
\text { decision- making processes, ensuring sus- } \\
\text { tainable working is integrated into the very } \\
\text { core of our business. }^{34}\end{array}$ & $\begin{array}{l}\text { common sense of direction and a culture } \\
\text { of performance and delivery. Our aim is to } \\
\text { create a successful, sustainable company } \\
\text { for the long term. To achieve this we need } \\
\text { to balance economic, social and environ- } \\
\text { mental issues in our decision- making } \\
\text { processes, ensuring sustainable working is } \\
\text { integrated into the very core of our busi- } \\
\text { ness. }\end{array}$ \\
\hline Hawk Scaffoldings & $\begin{array}{l}\text { Our Vision. Advancing each generation. } \\
\text { Since inception, the people of "Hawk" } \\
\text { have partnered to create innovative and } \\
\text { sustainable solutions that move the world } \\
\text { forward. Our Values. We live our Values } \\
\text { every day, everywhere, collaborating for } \\
\text { the benefit of our customers, investors, } \\
\text { employees, communities and partners } \\
\text { (plus } 40 \text { identical words). }{ }^{36}\end{array}$ & $\begin{array}{l}\text { Our Vision. (...) Advancing each genera- } \\
\text { tion. Since } 1888 \text {, the people of Alcoa have } \\
\text { partnered to create innovative and sustain- } \\
\text { able solutions that move the world for- } \\
\text { ward. Our Values. We live our Values } \\
\text { every day, everywhere, collaborating for } \\
\text { the benefit of our customers, investors, } \\
\text { employees, communities and partners. }\end{array}$ \\
\hline $\begin{array}{lr}\text { Henan } & \text { Chengfang- } \\
\text { yuan } & \text { International } \\
\text { Trading Company }\end{array}$ & $\begin{array}{l}\text { We remain firmly committed to sustaina- } \\
\text { ble development. Operating safely and } \\
\text { responsibly is embedded in everything we } \\
\text { do, and we continue to assess the econom- } \\
\text { ic, social and environmental risks and } \\
\text { benefits of every decision. }{ }^{38}\end{array}$ & $\begin{array}{l}\text { We remain firmly committed to sustaina- } \\
\text { ble development. Operating safely and } \\
\text { responsibly is embedded in everything we } \\
\text { do, and we continue to assess the econom- } \\
\text { ic, social and environmental risks and } \\
\text { benefits of every decision. }{ }^{39}\end{array}$ \\
\hline Henke Consulting & $\begin{array}{l}\text { Sustainability these days is a buzzword } \\
\text { used in many different contexts with many } \\
\text { different connotations. But what does it } \\
\text { mean for a HenkeConsulting.com? We at } \\
\text { HenkeConsulting don't just talk about } \\
\text { sustainability. We've made the three areas } \\
\text { of sustainable development - environment, } \\
\text { business and society - the cornerstone of } \\
\text { all our activities. }\end{array}$ & $\begin{array}{l}\text { Sustainability these days is a buzzword } \\
\text { used in many different contexts with many } \\
\text { different connotations. But what does it } \\
\text { mean for a multinational company? We at } \\
\text { Siemens don't just talk about sustainabil- } \\
\text { ity. We've made the three areas of sus- } \\
\text { tainable development - environment, } \\
\text { business and society - the cornerstone of } \\
\text { all our activities. }\end{array}$ \\
\hline Houthoff Buruma & $\begin{array}{l}\text { Sustainability is a buzzword used in many } \\
\text { different contexts with many different } \\
\text { connotations. }\end{array}$ & $\begin{array}{l}\text { Sustainability is a buzzword used in many } \\
\text { different contexts with many different } \\
\text { connotations. }{ }^{43}\end{array}$ \\
\hline Huatai Biopharm & $\begin{array}{l}\text { Huatai has long believed it is important for } \\
\text { us to care for the communities in which we } \\
\text { live and operate. Along with the compa- } \\
\text { ny's dedication to employees' cultivation as } \\
\text { well as technology research and develop- } \\
\text { ment, we are also very much devoted to } \\
\text { being a good corporate citizen. May it be } \\
\text { for cultural perseverance, and education }\end{array}$ & $\begin{array}{l}\text { AU Optronics (AUO) has long believed it } \\
\text { is important for us to care for the commu- } \\
\text { nities in which we live and operate. Along } \\
\text { with the company's dedication to employ- } \\
\text { ees' cultivation as well as technology } \\
\text { research and development, we are also } \\
\text { very much devoted to being a good corpo- } \\
\text { rate citizen. May it be for cultural perse- }\end{array}$ \\
\hline
\end{tabular}

\footnotetext{
${ }^{34} \mathrm{http} / / /$ globalrecruitme.com/about-candp.php

${ }^{35} \mathrm{http}: / / \mathrm{www} \cdot a m e c . c o m / a b o u t u s /$ sustainability/performance and engagement.htm

${ }^{36} \mathrm{https}: / /$ sites.google.com/site/hawkscalffoldings/

$37 \mathrm{http}: / / \mathrm{www} . a 1 c 0 a . c o m / g l o b a l /$ en/about alcoa/vision and values.asp

$38 \mathrm{http://www.cfychina.com/eng/Community} \mathrm{Projects.asp}$

$39 \mathrm{http}: / / \mathrm{www}$.angloamerican.com/development

${ }^{40} \mathrm{http} / / / \mathrm{www} \cdot h$ enkeconsulting.com/en/Who We Are/Entries/2014/3/1 Strategic with values and visions.html

${ }^{41} \mathrm{http}: / / \mathrm{www}$. siemens.com/sustainability/en/sustainability-at-siemens/our-understanding.htm

$42 \mathrm{http}: / /$ www.houthoff.com/about-us/values

${ }^{43} \mathrm{http}: / /$ www.siemens.com/sustainability/en/sustainability-at-siemens/our-understanding.htm
} 


\begin{tabular}{|c|c|c|}
\hline & $\begin{array}{l}\text { for the next generation (plus more than } \\
100 \text { almost identical words). }{ }^{4}\end{array}$ & $\begin{array}{l}\text { verance, and education for the next gener- } \\
\text { ation. }{ }^{45}\end{array}$ \\
\hline ICT Xchange & $\begin{array}{l}\text { The way we do business. (...) Our values } \\
\text { give us standards to measure ourselves by, } \\
\text { particularly in our dealings with custom- } \\
\text { ers, suppliers, our own people and the } \\
\text { wider world. The values have real meaning } \\
\text { for us and the way we behave. }{ }^{46}\end{array}$ & $\begin{array}{l}\text { The way we do business. (...) Our values } \\
\text { give us standards to measure ourselves by, } \\
\text { particularly in our dealings with custom- } \\
\text { ers, suppliers, our own people and the } \\
\text { wider world. The values have real mean- } \\
\text { ing for us and the way we behave. }{ }^{47}\end{array}$ \\
\hline Indus Towers & $\begin{array}{l}\text { At Indus, we measure our performance not } \\
\text { only in terms of what we do, but also how } \\
\text { we do it. We see Corporate Social Respon- } \\
\text { sibility (CSR) as a business imperative. }\end{array}$ & $\begin{array}{l}\text { At Alcatel-Lucent, we measure our per- } \\
\text { formance not only in terms of what we do } \\
\text { but also how we do it. We see Corporate } \\
\text { Responsibility as a business imperative. }{ }^{49}\end{array}$ \\
\hline $\begin{array}{l}\text { Innoexcel Technolo- } \\
\text { gies }\end{array}$ & $\begin{array}{l}\text { It stems from the belief that corporations } \\
\text { are socio-economic citizens and that their } \\
\text { objectives have to be congruent with socie- } \\
\text { ty's goals. Today, they wield significant } \\
\text { capacity to influence social issues, i.e. } \\
\text { "power to do good" (plus more than } 80 \\
\text { almost identical words). }\end{array}$ & $\begin{array}{l}\text { It stems from the belief that corporations } \\
\text { are socio-economic citizens and that their } \\
\text { objectives have to be congruent with soci- } \\
\text { ety's goals. Today, they wield significant } \\
\text { capacity to influence social issues, i.e. } \\
\text { "power to do good". }{ }^{1}\end{array}$ \\
\hline Joshua Energy & $\begin{array}{l}\text { We remain firmly committed to sustaina- } \\
\text { ble development. Operating safely and } \\
\text { responsibly is embedded in everything we } \\
\text { do, and we continue to assess the econom- } \\
\text { ic, social and environmental risks and } \\
\text { benefits of every decision. }{ }^{2}\end{array}$ & $\begin{array}{l}\text { We remain firmly committed to sustaina- } \\
\text { ble development. Operating safely and } \\
\text { responsibly is embedded in everything we } \\
\text { do, and we continue to assess the econom- } \\
\text { ic, social and environmental risks and } \\
\text { benefits of every decision. }{ }^{53}\end{array}$ \\
\hline K Laser Technology & $\begin{array}{l}\text { K Laser advocates and acts upon the prin- } \\
\text { ciples of operational transparency and } \\
\text { respect for shareholder rights. We believe } \\
\text { that the basis for successful corporate } \\
\text { governance is a sound and effective Board } \\
\text { of Directors. }{ }^{54}\end{array}$ & $\begin{array}{l}\text { TSMC advocates and acts upon the prin- } \\
\text { ciples of operational transparency and } \\
\text { respect for shareholder rights. We believe } \\
\text { that the basis for successful corporate } \\
\text { governance is a sound and effective Board } \\
\text { of Directors. } 55\end{array}$ \\
\hline Krishna Foils & $\begin{array}{l}\text { The highest standards of corporate behav- } \\
\text { ior towards everyone we work with, the } \\
\text { communities we touch, and the environ- } \\
\text { ment on which we have an impact. Con- } \\
\text { ducting our operations with integrity and } \\
\text { with respect for the many people, organi- } \\
\text { zations and environments our business } \\
\text { touches has always been at the heart of our } \\
\text { corporate responsibility. }{ }^{56}\end{array}$ & $\begin{array}{l}\text { Our Corporate Purpose states that to suc- } \\
\text { ceed requires "the highest standards of } \\
\text { corporate behaviour towards everyone we } \\
\text { work with, the communities we touch, and } \\
\text { the environment on which we have an } \\
\text { impact." (...) Conducting our operations } \\
\text { with integrity and with respect for the } \\
\text { many people, organisations and environ- } \\
\text { ments our business touches has always }\end{array}$ \\
\hline
\end{tabular}

\footnotetext{
${ }^{44} \mathrm{http}: / /$ www.huatai-biopharm.com/htweb/page.asp?bigclass $=5 \& \mathrm{id}=62$

$45 \mathrm{http}: / /$ auo.com/?sn=146\&lang=en-US

46 http://www.ictxchange.com/principles.html

${ }^{47} \mathrm{http} / / / \mathrm{www} \cdot$ akzonobel.com/corporate governance/introduction by ceo/

${ }^{48} \mathrm{http}: / / \mathrm{www}$. industowers.com/corporate responsibility.php

${ }^{49} \mathrm{http://www3.alcatel-lucent.com/sustainability/commitments.html}$

${ }^{50} \mathrm{http}: / / \mathrm{www}$. innoexcel.com/sustaniblity.aspx

${ }^{51}$ http://www.wipro.com/about-wipro/sustainability/

52 http://www.jrsenergy.co.za/joshua energy 006.htm

53 http://www.angloamerican.com/development

${ }^{54} \mathrm{http}: / /$ www.klasergroup.com/eng/Investor Detail.aspx?ID=ab34bb4c-8f02-4cba-83a8-08145ef25c7c

${ }^{55} \mathrm{http}: / / \mathrm{www} . t s m c . c o m /$ english/investorRelations/corporate governance.htm

${ }^{56} \mathrm{http://www.krishnafoils.com/quality} \mathrm{management.html}$
} 


\begin{tabular}{|c|c|c|}
\hline & & $\begin{array}{l}\text { been at the heart of our corporate respon- } \\
\text { sibility. }\end{array}$ \\
\hline Loyok & $\begin{array}{l}\text { I know others can be right and I recognize } \\
\text { the need for open communication, espe- } \\
\text { ciall customers. I shall listen to what others } \\
\text { say and change as the situation requires. I } \\
\text { shall remain open to new ideas. I know } \\
\text { success is impossible without change. } \\
\text { (plus more than } 100 \text { identical words). } .^{58}\end{array}$ & $\begin{array}{l}\text { Iobil know others can be right and I recog- } \\
\text { nize the need for open communication, } \\
\text { especiall customers. I shall listen to what } \\
\text { others say and change as the situation } \\
\text { requires. I shall remain open to new ideas. } \\
\text { I know success is impossible without } \\
\text { change. }{ }^{59}\end{array}$ \\
\hline Mailsoft Solutions & $\begin{array}{l}\text { It stems from the belief that corporations } \\
\text { are socio-economic citizens and that their } \\
\text { objectives have to be congruent with socie- } \\
\text { ty's goals. This is a responsibility and must } \\
\text { manifest in thoughtful and deliberate set of } \\
\text { initiatives, not in charity. These must re- } \\
\text { flect the same level of rigor \& strategic } \\
\text { thinking as in business initiatives. MSS } \\
\text { believes (plus more than } 50 \text { almost identi- } \\
\text { cal words). }{ }^{60}\end{array}$ & $\begin{array}{l}\text { It stems from the belief that corporations } \\
\text { are socio-economic citizens and that their } \\
\text { objectives have to be congruent with soci- } \\
\text { ety's goals }(\ldots) \text { This is a responsibility and } \\
\text { must manifest in thoughtful and deliberate } \\
\text { set of initiatives, not in charity. These } \\
\text { must reflect the same level of rigor \& } \\
\text { strategic thinking as in business initia- } \\
\text { tives. Wipro believes ... }\end{array}$ \\
\hline Marchad Group & $\begin{array}{l}\text { Provide leadership in thought } \& \text { action on } \\
\text { key societal issues. (...) Need to respond } \\
\text { to immediate issues of current genera- } \\
\text { tion. }{ }^{62}\end{array}$ & $\begin{array}{l}\text { Provide leadership in thought } \& \text { action on } \\
\text { key societal issues. Need to respond to } \\
\text { immediate issues of current generation. }{ }^{63}\end{array}$ \\
\hline Mezzan Holding & $\begin{array}{l}\text { 2. Company Principles. } 2.1 \text { Legal and } \\
\text { International Regulations. We comply } \\
\text { with the laws, rules and regulations of the } \\
\text { countries in which we conduct business. } \\
2.2 \text { Public Reporting and Communication. } \\
\text { Our financial statements, public reporting } \\
\text { documents and other public communica- } \\
\text { tion provide full, fair, accurate, timely and } \\
\text { understandable disclosure of the Compa- } \\
\text { ny's position in accordance with relevant } \\
\text { laws and generally accepted accounting } \\
\text { principles and standards (the companies } \\
\text { "principles" are actually almost a full } \\
\text { copy of the PostNL's official Business } \\
\text { Principles). }{ }^{64}\end{array}$ & $\begin{array}{l}\text { Principles that guide our company. Legal } \\
\text { and international regulations. We comply } \\
\text { with the laws, rules and regulations of the } \\
\text { countries in which we conduct business. } \\
\text { Public reporting and communication. Our } \\
\text { financial statements, public reporting } \\
\text { documents and other public communica- } \\
\text { tion provide full, fair, accurate, timely and } \\
\text { understandable disclosure of PostNL's } \\
\text { position in accordance with relevant laws } \\
\text { and generally accepted accounting princi- } \\
\text { ples and standards. }\end{array}$ \\
\hline Mostham PTY Ltd & $\begin{array}{l}\text { Megatrends - demographic change, urban- } \\
\text { ization, climate change and globalization - } \\
\text { are affecting and defining lives and econ- } \\
\text { omies throughout the world. These game- } \\
\text { changing forces are shaping our business } \\
\text { by creating new markets and opening up } \\
\text { valuable new opportunities. Yet they also }\end{array}$ & $\begin{array}{l}\text { Megatrends - demographic change, urban- } \\
\text { ization, climate change and globalization } \\
- \text { are affecting and defining lives and } \\
\text { economies throughout the world. These } \\
\text { game-changing forces are shaping our } \\
\text { business by creating new markets and } \\
\text { opening up valuable new opportunities. }\end{array}$ \\
\hline
\end{tabular}

\footnotetext{
${ }^{57} \mathrm{http} / / /$ www.unilever.com/aboutus/purposeandprinciples/

${ }^{58} \mathrm{http} / / /$ weezle.co.kr/wp/?page id=2

${ }^{59} \mathrm{http://en.amorepacific.com/about/about} \mathrm{ideology} \mathrm{01.jsp}$

${ }^{60} \mathrm{http}: / / \mathrm{www}$.mailsoftsolutions.com/Aboutus.aspx

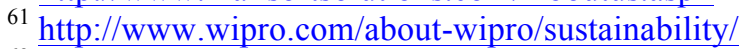

62 http://www.marchadgroup.com/spirit.html

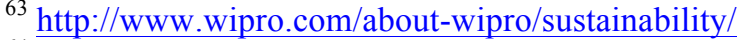

${ }_{65}^{64} \mathrm{http} / / / \mathrm{www} \cdot \mathrm{mezzan} . c 0 \mathrm{~m} /$ company-code-conduct.aspx

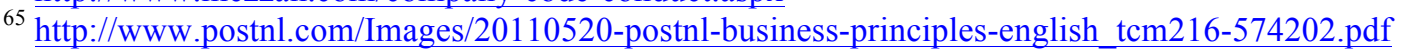




\begin{tabular}{|c|c|c|}
\hline & $\begin{array}{l}\text { harbor significant risks that need careful } \\
\text { management. Alone a value-based, sus- } \\
\text { tainability-driven company committed to } \\
\text { living its principles can minimize these } \\
\text { risks and master these challenges to opti- } \\
\text { mally leverage emerging opportunities for } \\
\text { its stakeholders. }\end{array}$ & $\begin{array}{l}\text { Yet they also harbor significant risks that } \\
\text { need careful management. Alone a value- } \\
\text { based, sustainability-driven company } \\
\text { committed to living its principles can } \\
\text { minimize these risks and master these } \\
\text { challenges to optimally leverage emerging } \\
\text { opportunities for its stakeholders. }{ }^{67}\end{array}$ \\
\hline Motibhai Group & $\begin{array}{l}\text { We are focussed on growing our business } \\
\text { responsibly, managing risks rather than } \\
\text { taking them and approach our role in soci- } \\
\text { ety with a heightened sense of duty and } \\
\text { care towards our customers and the com- } \\
\text { munities we serve. (Labelled as the CEO's } \\
\text { own mission statement) }\end{array}$ & $\begin{array}{l}\text { We are focussed on growing our business } \\
\text { responsibly, managing risks rather than } \\
\text { taking them and approach our role in } \\
\text { society with a heightened sense of duty } \\
\text { and care towards our customers and the } \\
\text { communities we serve. - Mike Smith, } \\
\text { ANZ CEO }^{69}\end{array}$ \\
\hline Oyster Tech & $\begin{array}{l}\text { Conducting our operations with integrity } \\
\text { and with respect for the many people, } \\
\text { organizations and environments our busi- } \\
\text { ness touches, has always been at the heart } \\
\text { of our corporate responsibility. }\end{array}$ & $\begin{array}{l}\text { Conducting our operations with integrity } \\
\text { and with respect for the many people, } \\
\text { organisations and environments our busi- } \\
\text { ness touches has always been at the heart } \\
\text { of our corporate responsibility. }\end{array}$ \\
\hline ProFactory Res & $\begin{array}{l}\text { Our Values. Our values give us standards } \\
\text { to measure ourselves by, particularly in } \\
\text { our dealings with customers, suppliers, our } \\
\text { own people and the wider world. The val- } \\
\text { ues have real meaning for us and the way } \\
\text { we behave. }{ }^{72}\end{array}$ & $\begin{array}{l}\text { Our values. Our values give us standards } \\
\text { to measure ourselves by, particularly in } \\
\text { our dealings with customers, suppliers, } \\
\text { our own people and the wider world. The } \\
\text { values have real meaning for us and the } \\
\text { way we behave. }\end{array}$ \\
\hline Prosertec Ing & $\begin{array}{l}\text { Corporate ethics and responsibility. PRO- } \\
\text { SERTEC is committed to the best corpo- } \\
\text { rate governance practices, to principles of } \\
\text { business ethics, and to transparency in all } \\
\text { of the Company's fields of endeavor. } \\
\text { PROSERTEC acts in furtherance of the } \\
\text { corporate interest, understood as the com- } \\
\text { mon interest of all shareholders of an in- } \\
\text { dependent (plus more than } 300 \text { almost } \\
\text { identical words). }{ }^{74}\end{array}$ & $\begin{array}{l}\text { Corporate ethics and responsibility. } \\
\text { IBERDROLA is committed to the best } \\
\text { corporate governance practices, to princi- } \\
\text { ples of business ethics, and to transparen- } \\
\text { cy in all of the Company's fields of en- } \\
\text { deavor. IBERDROLA acts in furtherance } \\
\text { of the corporate interest, understood as the } \\
\text { common interest of all shareholders of an } \\
\text { independent ... }\end{array}$ \\
\hline Rudisa Holidng & $\begin{array}{l}\text { Always working with Integrity. Conduct- } \\
\text { ing our operations with integrity and with } \\
\text { respect for the many people, organizations } \\
\text { and environments our business touch has } \\
\text { always been at the heart of our corporate } \\
\text { responsibility. }{ }^{76}\end{array}$ & $\begin{array}{l}\text { ALWAYS WORKING WITH INTEGRI- } \\
\text { TY. Conducting our operations with integ- } \\
\text { rity and with respect for the many people, } \\
\text { organisations and environments our busi- } \\
\text { ness touches has always been at the heart } \\
\text { of our corporate responsibility. }\end{array}$ \\
\hline Sanchar Telecom & At Sanchar, we measure our performance & At Alcatel-Lucent, we measure our per- \\
\hline
\end{tabular}

\footnotetext{
${ }^{66} \mathrm{http}: / /$ mostham.com/Sustainability.aspx

${ }^{67} \mathrm{http}: / / \mathrm{www}$. siemens.com/sustainability/en/sustainability-at-siemens/index.php

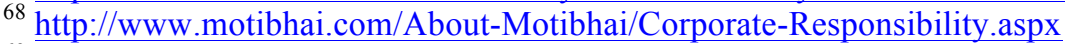

${ }^{69} \mathrm{http} / / / \mathrm{www} \cdot$ anz.com.au/about-us/corporate-responsibility/

${ }^{70} \mathrm{http}: / /$ www.oystertechnologies.com/page0/page0.html

${ }^{71} \mathrm{http}: / /$ www.unilever.com/aboutus/purposeandprinciples/

$72 \mathrm{http} / / / \mathrm{www}$. profactory.com.hk/management.html

$73 \mathrm{http}: / / \mathrm{www} \cdot$ akzonobel.com/corporate governance/introduction by ceo/

${ }^{74} \mathrm{http}: / / \mathrm{www}$. prosertec-srl.com/en/la-empresa

${ }^{75} \mathrm{http}: / /$ www.iberdrola.es/webibd/corporativa/iberdrola?IDPAG=ENWEBCONEMPGVISIONYVAL

${ }^{76} \mathrm{http}: / / \mathrm{www}$. rudisa.net/smartcms/defaultcb54.asp? contentID $=602$

$77 \mathrm{http}: / /$ www.unilever.com/aboutus/purposeandprinciples/
} 


\begin{tabular}{|c|c|c|}
\hline & $\begin{array}{l}\text { not only in terms of what we do, but also } \\
\text { how we do it. We see Corporate Social } \\
\text { Responsibility (CSR) as a business im- } \\
\text { perative. }^{78}\end{array}$ & $\begin{array}{l}\text { formance not only in terms of what we do } \\
\text { but also how we do it. We see Corporate } \\
\text { Responsibility as a business imperative. }\end{array}$ \\
\hline SCC Pvt Ltd & $\begin{array}{l}\text { SCC Cares engages with communities in } \\
\text { our proximate locations. The primary ob- } \\
\text { jectives of SCC Cares are to support the } \\
\text { developmental needs of marginalized } \\
\text { communities in cities where SCC has a } \\
\text { presence. }^{80}\end{array}$ & $\begin{array}{l}\text { Wipro Cares engages with communities in } \\
\text { our proximate locations. The primary } \\
\text { objectives of Wipro Cares are to support } \\
\text { the developmental needs of marginalized } \\
\text { communities in cities and towns where } \\
\text { Wipro has a large presence. }\end{array}$ \\
\hline Sciformix & $\begin{array}{l}\text { We live our mission of helping people live } \\
\text { healthier lives; and our values of integrity, } \\
\text { commitment, focus, innovation, diversity, } \\
\text { excellence and teamwork every day, in } \\
\text { everything we do. Giving, volunteering } \\
\text { and business innovations are the ways in } \\
\text { which we live our mission and respond to } \\
\text { the needs of our communities. Each is } \\
\text { important; together they become a power- } \\
\text { ful commitment to improving health, peo- } \\
\text { ple's lives and communities. When hun- } \\
\text { dreds of people decide to make a differ- } \\
\text { ence, anything is possible. }\end{array}$ & $\begin{array}{l}\text { We live our mission of helping people live } \\
\text { healthier lives; our focus of helping the } \\
\text { health care system work better for every- } \\
\text { one; and our values of integrity, compas- } \\
\text { sion, relationships, innovation and per- } \\
\text { formance every day, in everything we do. } \\
\text { Giving, volunteering and business innova- } \\
\text { tions are the ways in which we live our } \\
\text { mission and respond to the needs of our } \\
\text { communities. Each is important; together } \\
\text { they become a powerful commitment to } \\
\text { improving health, people's lives and } \\
\text { communities. When } 99,000 \text { people decide } \\
\text { to make a difference, anything is possi- } \\
\text { ble. }\end{array}$ \\
\hline ScottishPower & $\begin{array}{l}\text { ScottishPower is committed to the best } \\
\text { corporate governance practices, to princi- } \\
\text { ples of business ethics, and to transparency } \\
\text { in all of the company's fields of endeav- } \\
\text { or. }{ }^{84}\end{array}$ & $\begin{array}{l}\text { IBERDROLA is committed to the best } \\
\text { corporate governance practices, to princi- } \\
\text { ples of business ethics, and to transparen- } \\
\text { cy in all of the Company's fields of en- } \\
\text { deavor. }\end{array}$ \\
\hline $\begin{array}{l}\text { Silver Dollar Tech- } \\
\text { nologies }\end{array}$ & $\begin{array}{l}\text { Our Values. Our values give us standards } \\
\text { to measure ourselves by particularly in our } \\
\text { dealings with customers, associates, affili- } \\
\text { ates and our own people within the Group. } \\
\text { The values have real meaning for us and } \\
\text { the way we behave. (...) Above all, we're } \\
\text { committed to creating long-term value for } \\
\text { our customers, shareholders, employees } \\
\text { and society (plus over } 100 \text { almost identical } \\
\text { words). }\end{array}$ & $\begin{array}{l}\text { Our Values. Our values give us standards } \\
\text { to measure ourselves by particularly in our } \\
\text { dealings with customers, associates, affili- } \\
\text { ates and our own people within the Group. } \\
\text { The values have real meaning for us and } \\
\text { the way we behave. (...) Above all, we're } \\
\text { committed to creating long-term value for } \\
\text { our customers, shareholders, employees } \\
\text { and society. }\end{array}$ \\
\hline Sollan Ltd & $\begin{array}{l}\text { The mission of SOLLAN Technology is to } \\
\text { become a GREAT company of world-class } \\
\text { excellence in business scale, products, }\end{array}$ & $\begin{array}{l}\text { The vision of Lite-On Technology is to } \\
\text { become a company of world-class excel- } \\
\text { lence in terms of business scale, products, }\end{array}$ \\
\hline
\end{tabular}

\footnotetext{
${ }^{78} \mathrm{http}: / / \mathrm{www} \cdot$ sanchartelecom.in/about

${ }^{79} \mathrm{http}: / / \mathrm{www} 3$. alcatel-lucent.com/sustainability/commitments.html

${ }^{80} \mathrm{http} / / / \mathrm{www} \cdot \mathrm{sccp} v t \mathrm{ttd} . \mathrm{com}$

81 http://www.wipro.com/about-wipro/sustainability/

$82 \mathrm{http}: / /$ www.sciformix.com/about-us/corporate-responsibility/

$83 \mathrm{http}: / /$ www.unitedhealthgroup.com/Social\%20Responsibility/Default.aspx

${ }^{84} \mathrm{http} / / / \mathrm{www} . \mathrm{scottishpowercsrannualreview.com/} \mathrm{content/review2009.pdf}$

${ }^{85} \mathrm{http}: / /$ www.iberdrola.es/webibd/corporativa/iberdrola?IDPAG=ENWEBCONEMPGVISIONYVAL

${ }^{86} \mathrm{http}: / / \mathrm{www} \cdot$ silverdollartech.com

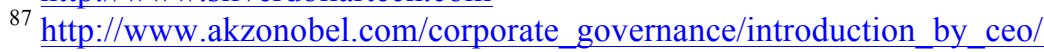




\begin{tabular}{|c|c|c|}
\hline & $\begin{array}{l}\text { corporate governance, and corporate social } \\
\text { responsibility. } 88\end{array}$ & $\begin{array}{l}\text { corporate governance, and corporate so- } \\
\text { cial responsibility. }{ }^{89}\end{array}$ \\
\hline Southern Folder & $\begin{array}{l}\text { 1. Refusal to Engage in Unfair Competi- } \\
\text { tion: As an industry leader, Southern Fol- } \\
\text { ger does not tolerate unfair practices to } \\
\text { compete and win business. All our selec- } \\
\text { tion and purchasing decisions are made } \\
\text { objectively, based on price, delivery, quali- } \\
\text { ty, and other factors and we expect that our } \\
\text { clients and suppliers will do the same. We } \\
\text { independently determine our own pricing } \\
\text { and financial deals and we do not make } \\
\text { agreements with competitors to divide } \\
\text { markets or clients (plus more than } 200 \\
\text { almost identical words). } .^{90}\end{array}$ & $\begin{array}{l}\text { 1. Refusal to Engage in Unfair Competi- } \\
\text { tion: (...) As a global leader, Sodexo does } \\
\text { not tolerate unfair practices to compete } \\
\text { and win business. All of our selection and } \\
\text { purchasing decisions are made objective- } \\
\text { ly, based on price, delivery, quality and } \\
\text { other factors, and we expect that our cli- } \\
\text { ents and suppliers will do the same. (...) } \\
\text { we independently determine our own } \\
\text { pricing and financial deals and we do not } \\
\text { make agreements with competitors to } \\
\text { divide markets or clients. }\end{array}$ \\
\hline Spark Company & $\begin{array}{l}\text { We envision SPARK to be a workplace } \\
\text { with an open and energetic atmosphere. } \\
\text { With our strong belief in the value of } \\
\text { SPARK 's highly competent people, we } \\
\text { will be working together innovatively, } \\
\text { while living SPARK 's four core values } \\
\text { and firmly adhering to ethical conduct. By } \\
2015 \text {, SPARK will have developed a more } \\
\text { diverse workplace with a customer-centric } \\
\text { mindset and global perspective. }\end{array}$ & $\begin{array}{l}\text { We envision SCG to be a workplace with } \\
\text { an open and energetic atmosphere. With } \\
\text { our strong belief in the value of SCG's } \\
\text { highly competent people, we will be } \\
\text { working together innovatively, while } \\
\text { living SCG's four core values and firmly } \\
\text { adhering to ethical conduct. By 2015, } \\
\text { SCG will have developed a more diverse } \\
\text { workplace with a customer-centric mind- } \\
\text { set and global perspectives. }{ }^{93}\end{array}$ \\
\hline $\begin{array}{l}\text { Sportsware Interna- } \\
\text { tional }\end{array}$ & $\begin{array}{l}\text { They help us to create brands that our } \\
\text { customers believe in and they commit us } \\
\text { to playing by the rules that society expects } \\
\text { of a responsible company. Society's rules } \\
\text { are not always written down. We discover } \\
\text { them by engaging with the people that our } \\
\text { business touches, learning above all that } \\
\text { companies are expected to be accountable } \\
\text { for their actions (plus more than } 60 \text { almost } \\
\text { identical words). }\end{array}$ & $\begin{array}{l}\text { They help us to create brands that our } \\
\text { customers believe in and they commit us } \\
\text { to playing by the rules that society expects } \\
\text { of a responsible company. Unlike sport, } \\
\text { society's rules are not always written } \\
\text { down. We discover them by engaging } \\
\text { with the people that our business touches, } \\
\text { learning above all that companies are } \\
\text { expected to be accountable for their ac- } \\
\text { tions. }\end{array}$ \\
\hline Sprint Energies & $\begin{array}{l}\text { Sprint Energies GmbH's aim is to ensure } \\
\text { the right balance between better business, } \\
\text { cleaner environment, and better lives. This } \\
\text { vision is further underpinned by our ambi- } \\
\text { tion to change the world together with our } \\
\text { customers. }\end{array}$ & $\begin{array}{l}\text { Novozymes' vision is to ensure the right } \\
\text { balance between better business, cleaner } \\
\text { environment, and better lives. This vision } \\
\text { is further underpinned by our ambition to } \\
\text { change the world together with our cus- } \\
\text { tomers. }\end{array}$ \\
\hline Sunflex Technology & $\begin{array}{l}\text { Sunflex advocates and acts upon the prin- } \\
\text { ciples of operational transparency and }\end{array}$ & $\begin{array}{l}\text { TSMC advocates and acts upon the prin- } \\
\text { ciples of operational transparency and }\end{array}$ \\
\hline
\end{tabular}

\footnotetext{
${ }^{88} \mathrm{http}: / /$ www.sollan.cn/termsc.php

${ }^{89} \mathrm{http}: / /$ www.liteon.com/Page.aspx?id=1a6b7429-2869-4dae-933e-b97465bcffac

${ }^{90} \mathrm{http} / / / \mathrm{www}$. southernfolger.com/files/UNGC 2012.pdf

91 http://www.sodexo.com/en/Images/sodexo-statement-of-business-integrity-130111342-564085.pdf

$92 \mathrm{http://spark-company.blogspot.fr/2012/01/vision.html}$

${ }_{93} \mathrm{http}: / /$ www.scg.co.th/en/01 corporate profile/02 scg vision.html

$94 \mathrm{http} / / / \mathrm{www}$. swi.co.uk/pu+school-uniform+corporate-responsibility+vision/

${ }^{95} \mathrm{http}: / /$ www.adidas-group.com/en/sustainability/Our Programme/Our sustainability statement/default.aspx

${ }^{96} \mathrm{http}: / /$ sprintenergies.com

${ }^{97}$ http://www.novozymes.com/en/about-us/vision-and-values/Pages/default.aspx
} 


\begin{tabular}{|c|c|c|}
\hline & $\begin{array}{l}\text { respect for shareholder rights. We believe } \\
\text { that the basis for successful ... }\end{array}$ & $\begin{array}{l}\text { respect for shareholder rights. We believe } \\
\text { that the basis for successful ... }\end{array}$ \\
\hline Syrox & $\begin{array}{l}\text { Using today's success to create tomorrow's } \\
\text { values: Business success is made by peo- } \\
\text { ple, for people. In order to develop it re- } \\
\text { quires a functioning society and a pleasant } \\
\text { environment to live in. That is why we } \\
\text { take on responsibility. Out of conviction } \\
\text { and in our own interests - now and in the } \\
\text { future. }\end{array}$ & $\begin{array}{l}\text { Using today's success to create tomorrow's } \\
\text { values: Business success is made by peo- } \\
\text { ple, for people. In order to develop it re- } \\
\text { quires a functioning society and a pleasant } \\
\text { environment to live in. That is why we } \\
\text { take on responsibility. Out of conviction } \\
\text { and in our own interests - now and in the } \\
\text { future. }\end{array}$ \\
\hline $\begin{array}{l}\text { The Graffiti Special- } \\
\text { ists }\end{array}$ & $\begin{array}{l}\text { Always working with integrity. Conduct- } \\
\text { ing our operations with integrity and with } \\
\text { respect for the many people, organizations } \\
\text { and environments our business touches has } \\
\text { always been at the heart of our corporate } \\
\text { responsibility (plus more than } 100 \text { almost } \\
\text { identical words). }{ }^{102}\end{array}$ & $\begin{array}{l}\text { ALWAYS WORKING WITH INTEGRI- } \\
\text { TY. Conducting our operations with integ- } \\
\text { rity and with respect for the many people, } \\
\text { organisations and environments our busi- } \\
\text { ness touches has always been at the heart } \\
\text { of our corporate responsibility. }{ }^{103}\end{array}$ \\
\hline $\begin{array}{l}\text { Wrapid Manufactur- } \\
\text { ing }\end{array}$ & $\begin{array}{l}\text { Conducting our operations with integrity } \\
\text { and with respect for the many people and } \\
\text { organisations our business touches has } \\
\text { always been the cornerstone for our Com- } \\
\text { pany. }{ }^{104}\end{array}$ & $\begin{array}{l}\text { Conducting our operations with integrity } \\
\text { and with respect for the many people, } \\
\text { organisations and environments our busi- } \\
\text { ness touches has always been at the heart } \\
\text { of our corporate responsibility. }\end{array}$ \\
\hline Zoonar Oil and Gas & $\begin{array}{l}\text { Zoonar Oil and Gas Limited was ranked } \\
\text { the industry leader for oil equipment and } \\
\text { services in the worldwide Dow Jones Sus- } \\
\text { tainability for } 2011-2012 \text {. This is the } \\
\text { third year in succession that Zoonar Oil } \\
\text { has been industry leader and the eighth } \\
\text { year in succession that it has featured in } \\
\text { the DJSI, which annually surveys and } \\
\text { benchmarks the world's } 2,500 \text { largest com- } \\
\text { panies (plus more than } 40 \text { almost identical } \\
\text { words). }{ }^{105}\end{array}$ & $\begin{array}{l}\text { In } 2012 \text { AMEC was ranked the industry } \\
\text { leader for oil equipment and services in } \\
\text { the worldwide Dow Jones Sustainability } \\
\text { Index (DJSI) for } 2012 \text { - 2013. This is the } \\
\text { fourth year in succession that AMEC has } \\
\text { been industry leader and the ninth year in } \\
\text { succession that it has featured in the DJSI, } \\
\text { which annually surveys and benchmarks } \\
\text { the world's } 2,500 \text { largest companies. }{ }^{106}\end{array}$ \\
\hline
\end{tabular}

\footnotetext{
${ }^{98} \mathrm{http}: / /$ www.sunflex.com.tw/eng/CSR.php

${ }^{99} \mathrm{http}: / / \mathrm{www} . t s m c . c o m /$ english/investorRelations/corporate governance.htm

${ }^{100} \mathrm{http}: / /$ www.syrox.co.il/eng/lego tree.php?instance id=1

101 http://www.bmwgroup.com/e/0 0 www bmwgroup com/verantwortung/verantwortung 2011.html

$102 \mathrm{http} / / / \mathrm{www}$. graffitispecialists.com.au/mission.htm

103 http://www.unilever.com/aboutus/purposeandprinciples/

$104 \mathrm{http}: / /$ www.wrapid-converting.com/about.php

$105 \mathrm{http}: / /$ zoonaroil.com/

$106 \mathrm{http}: / / \mathrm{www} . a m e c . c o m / a b o u t u s /$ sustainability/performance and engagement.htm
} 